\title{
Synthesis of mesh-shaped calcia partially stabilized zirconia using eggshell membrane template as filler composite
}

\author{
Gema Gempita*, Zulia Hasratiningsih**, Gantini Subrata***, Bambang Sunendar \\ Purwasasmita****
}

*Community Health Centre of Pasirsakti Lampung Ministry of Health Republic of Indonesia

**Department of Dental Materials Science and Technology Faculty of Dentistry Universitas

Padjadjaran, Indonesia

***Department of Prosthodontic, Faculty of Dentistry Universitas Padjadjaran, Indonesia

****Department of Phycics Engineering, Bandung Institute of Technology, Indonesia

\begin{abstract}
Introduction: This experiment was conducted experimentally to synthesize Calcia Partially Stabilized Zirconia (Ca-PSZ) by sol-gel method using eggshell membrane template as a composite filler. The eggshell membrane was used to produce a mesh shaped structure, which hopefully can improve the mechanical properties of the composite. Method: Ca-PSZ filler was synthesized from $\mathrm{ZrOCl}_{2}$ precursor and $\mathrm{Ca}\left(\mathrm{NO}_{3}\right)_{2}$ stabilizer with a 24 hours immersion time. Ca-PSZ of synthesis then mixed with the resin matrix to test its composite hardness. Result: The EDS characterization results suggested that the sample contained elements of zirconia, calcium, and oxygen. Whereas, the XRD characterization identified that crystal structures that formed in the sample were nano scale tetragonal. Characterization of SEM showed Ca-PSZ with mesh structured. The average composite hardness value was $15.79 \mathrm{VHN}$. Conclusion: The composites with Ca-PSZ-synthesized filler could be prepared and its hardness value was higher than the composite with Ca-PSZ filler in spherical particles, but the hardness was still below the composite on the market.
\end{abstract}

Keywords: Ca-PSZ filler, sol-gel method, eggshell membrane template, composite hardness

P-ISSN 1979-0201, e-ISSN 2549-6212 Available from:http://jurnal.unpad.ac.id/pjd/index

DOI:http://dx.doi.org/10.24198/pjd.vol29no2.13603

Submission: May 2017 Publishing: July 2017

\section{INTRODUCTION}

The composite is the combination of two or more chemically different materials that are combined with the aim of improving their physical and mechanical properties, rather than when one component stands alone. ${ }^{1}$ The composite consists of an organic resin matrix and an inorganic filler particle that are combined into one by coupling agent. $^{2}$ Composites in the practice of dentistry are used as anterior filling material only, but as the composite developed, it also has been used as a posterior dental material, onlays/inlays, and veneer. $^{3}$ 
Hardness is an important factor in composite materials. Hardness is required in order to resist wear or abrasion when used in the oral cavity. One of the things that affect the hardness of the composite is the type and size of the filler. ${ }^{3}$ Some of the fillers in the composites are silicate zinc, silica, barium silica, quartz, aluminum silica, and zirconia. 4,5

Zirconia is one type of ceramic that has been used in a nano-filler composites. Zirconia is widely used as a composite filler due to its excellent mechanical properties and its radiopaque image in radiology images. ${ }^{6}$ Partially Stabilized Zirconia (PSZ) is an attempt to synthesize zirconia by adding stabilizers such as $\mathrm{CaO}, \mathrm{MgO}, \mathrm{Y}_{2} \mathrm{O}_{3}$ in a certain amount. The addition of this stabilizer has been shown to stabilize zirconia at room temperature, so that it can cause transformation toughening phenomenon which can improve the mechanical properties of zirconia when spontaneous cracking occur. $^{7}$

The sol-gel method is one of the simplest methods of preparing a zirconia-based composite filler. It does not need a long operation, is relatively in low heating temperature and low cost. The use of sol-gel method can produce nano-sized with structured materials by using a template in the process. The template serves as a mold or substrate on where the inorganic particles grow. ${ }^{8,9}$

One of the most widely developed templates, due to its large number in nature, environmentally friendly property, and biocompatibility, is the eggshell membrane. The eggshell membrane has a mesh-shaped structure. ${ }^{10}$ The mesh structure of the filler can increase the surface area so it is expected to improve the mechanical properties of the composite. ${ }^{11}$ Composites with nano zirconia fillers on the market are all expensive imported products, so the authors would like to try to make their own composite material by using eggshell membrane as a template to produce a Ca-PSZ structured mesh filler.

\section{METHODS}

The method used in this study was the experimental method in the laboratory. The research was conducted at Integrated Materials Process Laboratory of Physics Engineering Institute of Technology Bandung (ITB).
This research used $\mathrm{ZrOCl}_{2}$ precursor with concentration $0.05 \mathrm{M}$, stabilizer $\mathrm{Ca}\left(\mathrm{NO}_{3}\right)_{2} 7 \mathrm{~mol}$ $\%$, chitosan as a dispersant and chelating agent and outer membrane part of eggshell membrane as the template.

The steps taken in this research was making the sol-gel solution by mixing $\mathrm{ZrOCl}_{2}, \mathrm{Ca}\left(\mathrm{NO}_{3}\right)_{2}$, and chitosan. The eggshell membrane template was immersed in a sol-gel solution for 24 hours. The eggshell membrane then removed and then calcined at $700^{\circ} \mathrm{C}$ so that the eggshell membrane would be lost and produced Ca-PSZ powder. The synthesized Ca-PSZ powder was then characterized using EDS, XRD, and SEM to check its compositions and crystal structures.

The resulting powder of Ca-PSZ was then made into filler in the composite making. In this study, the composition of the composite used is as much as $40 \mathrm{wt} \%$ filler, $60 \mathrm{wt} \%$ matrix, photoinitiator, accelerator, and inhibitor. The synthesized Ca-PSZ powder is weighed according to the calculation and then immersed into chitosan solution and dry using vacuum and oven. After drying, the powder is mixed with a mixture of matrices consisting of UDMA, TEGDMA, DMAEMA, Chomporquinone, and Butylated hydroxytoluene and then stirred with a spatula into a paste.

The formed paste was put into a circular mold with a diameter of $6 \mathrm{~mm}$ and a thickness of $3 \mathrm{~mm}$, flattened with a plastic instrument and irradiated with Light Curing Unit (LCU) Woodpecker LED.D. Then a composite specimen of a circle that has been hard tested the hardness value of its microvickers.

The microvickers hardness test was conducted at the Laboratory of the Faculty of Mining and Petroleum ITB using the LECO-Japan-M$400-\mathrm{H} 1 / \mathrm{H} 2 / \mathrm{H} 3$ testing machine. In this test, three specimens were used, in which each specimen was indexed at five points for 15 seconds with a load of $0.1 \mathrm{~kg}$. Then the result is on average to get the value of its microvickers hardness.

\section{RESULTS}

Energy Dispersive X-Ray Spectroscopy (EDS/EDX) is a technique used to analyze chemical elements of materials and to investigate the sample contents. ${ }^{12}$ From EDS characterization, it could be seen that the elements contained in the sample 
were zirconia, oxygen, and calcium. Thus, it could be confirmed that the formed elements were predominantly zirconia and not residual carbon from the burning of eggshell membrane.

X-Ray Diffraction (XRD) characterization was used to identify the crystalline phase in the sample. ${ }^{13}$ Characterization using X-Ray Diffraction (XRD) was performed on the sample to determine

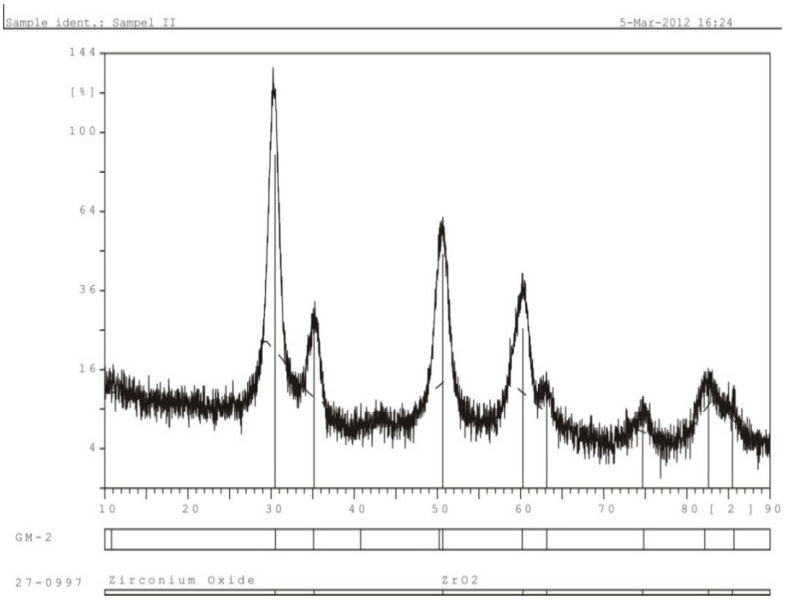

Figure 1. XRD Characterization of the sample

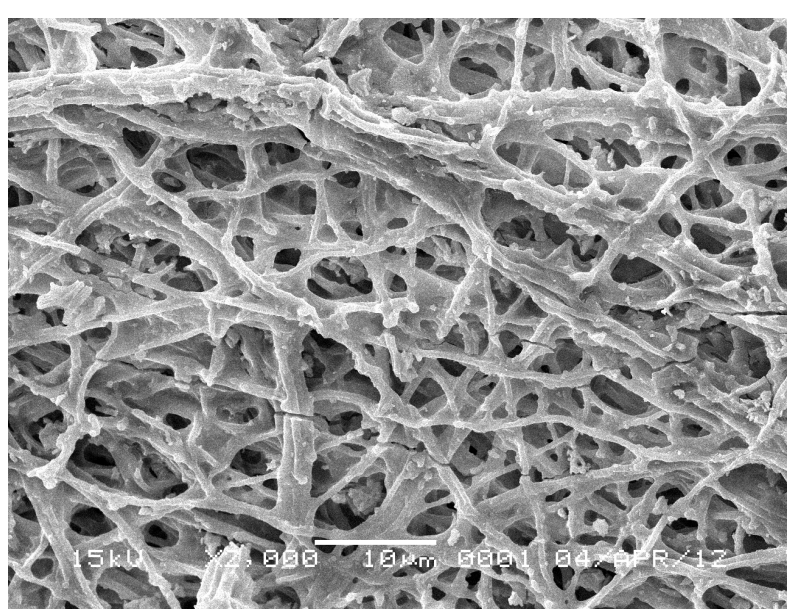

Figure 2. SEM Characterization of the sample, with $10.000 x$ enlargement the shape and the size of the crystal structure that formed of the sample. The XRD results (Fig.1) could be interpreted using $X$ Powder software, which the sample showed that it formed nanoscale tetragonal zirconia crystals.

Scanning Electron Microscopy (SEM) characterization was performed to determine the microstructure and the surface morphology of the sample. ${ }^{14}$ From the SEM results (Figure 2), it could be seen that the morphology of Ca-PSZ took after the morphology of eggshell membrane, mesh shaped structure.

From microvickers hardness test, there were 3 composite specimens that were made by using $\mathrm{Ca}$-PSZ filler from the synthesis. Indentations were done at five points from each specimen, which then calculated to get the average value. Then, the average value of all three specimens was calculated (Table 1), which was 15.79 VHN.

\section{DISCUSSION}

EDS and XRD characterization showed the elements contained in the sample were zirconia, oxygen, and calcium with crystallite formed on nano-sized. From the SEM results in the sample, it could be seen that the morphology of Ca-PSZ resembled the morphology of eggshell morphology, mesh-shape morphology. This proves that there had been a bond between the eggshell membrane and $\mathrm{ZrO}_{2}$ when the immersion process in sol-gel solution. The eggshell membrane consists of a protein containing an $\mathrm{OH}$-group that can bind to metal oxides such as $\mathrm{ZrO}_{2}{ }^{9}{ }^{9,10}$ When the eggshell membrane is immersed into a sol-gel solution, the $\mathrm{ZrO}_{2}$ particles will bind to the $\mathrm{OH}$-group of the eggshell membrane. After calcination at $700^{\circ} \mathrm{C}$ temperature, the eggshell membrane which contained protein will vanish, so that only

Table 1. The microvickers hardness values of the three specimens

\begin{tabular}{cccccccccc}
\hline \multirow{2}{*}{ Point } & \multicolumn{3}{c}{ Specimen 1 } & \multicolumn{3}{c}{ Specimen 2 } & \multicolumn{3}{c}{ Specimen 3 } \\
\cline { 2 - 9 } & d1 & d2 & VHN & d1 & d2 & VHN & d1 & d2 & VHN \\
\hline 1 & 107.69 & 107.53 & 16 & 111.46 & 109.19 & 15.2 & 108.63 & 106.91 & 16.0 \\
2 & 100.66 & 101.06 & 18.2 & 112.71 & 108.39 & 15.2 & 110.09 & 107.83 & 15.6 \\
3 & 104.68 & 103.26 & 17.2 & 111.27 & 112.91 & 14.8 & 112.97 & 105.62 & 15.5 \\
4 & 109.44 & 101.02 & 16.7 & 105.03 & 104.71 & 16.9 & 110.07 & 113.09 & 14.9 \\
5 & 105.95 & 115.76 & 15.1 & 111.33 & 116.17 & 14.3 & 109.78 & 110.83 & 15.2 \\
\hline VHN & & & $\mathbf{1 6 . 6 4}$ & & & $\mathbf{1 5 . 2 8}$ & & & $\mathbf{1 5 . 4 4}$ \\
\hline
\end{tabular}


remained were $\mathrm{ZrO}_{2}$ particles that took after the morphology of the eggshell membrane. The result of this synthesis was a powder that next would be used as filler in the composite.

The composite is a material that consisted of an organic resin matrix and an inorganic filler particle combined into one by coupling agent. ${ }^{2}$ The composite specimens, that were used to test the microvickers hardness in this study, were created using the synthesized Ca-PSZ (Calcia-Partially Stabilized Zirconia) filler. This test is used to determine the value of surface hardness on brittle materials, such as ceramics composites, and also to test the hardness of a material with a small specimen. ${ }^{1,7}$ In this study, the average value of the microvickers hardness of all three specimens was 15.79 VHN.

The microvickers hardness values of the specimens were still below the composite on the market, proposed by McCabe and Angus ${ }^{15}$, which is $30-90 \mathrm{VHN}$. Some things that affect hardness in composites are the type and size of filler and also the percentage of filler and matrix that are contained in the composite..$^{3,16}$

The low hardness values in this study could be caused by the type of matrix that was used. In this study, UDMA and TEDGMA were used as matrixes, while the commercial composite in the market used the Bis-GMA. Bis-GMA is derived from the reaction of glycidyl methacrylate with bisphenol-A, it has high viscosity. On the other hand, UDMA and TEDGMA have lower viscosity compared to Bis-GMA. The low viscosity could reduce the hardness of composite. ${ }^{2,3}$

Another cause of the low hardness value might be created from improper composition between the matrix and the filler. In this study, the percentages of filler were very small compared to the matrix. The low percentages of filler will degrade the hardness of the composite. ${ }^{16}$

The type of filler that used in this study has also had the possibility of affecting the hardness. In this study, the filler was zirconia (Ca-PSZ), whereas the composites in the market the filler usually consist of a mixture of zirconia, silica, quartz, and others. Zirconia is known to have nonreactive surface properties, so it is not easy to react with other materials. Special treatments may be required, such as adding and coating zirconia with silica or alumina that will bind the surface mechanically. ${ }^{6,17}$ In this study, the zirconia was not given any special treatment.

Compared with the research conducted by Putri ${ }^{18}$, which examined the hardness value of composite microvickers by using a particulate spherical Ca-PSZ filler, the hardness value in this study was greater. Putri ${ }^{18}$ used composites with filler and matrix with ratio $70: 30 \mathrm{wt} \%$. The result of the microvickers hardness value was $13.13 \mathrm{VHN}$. The hardness value in this study was greater than in Putri ${ }^{18}$ studies. This may be due to the meshshaped of Ca-PSZ filler. Pinho' ${ }^{11}$ said that mesh structure can improve the mechanical properties of composites.

\section{CONCLUSION}

The conclusion of this research was that the composite could be produced using the Ca-PSZ filler with mesh structure that synthesized by sol-gel method using eggshell membrane as the template. The mesh structure of the filler could increase the hardness of composites.

\section{REFERENCES}

1. Powers JM, Sakaguchi RL. Craig's restorative dental materials. $12^{\text {th }}$ ed. St. Louis: Elsevier Inc.; 2006. p. 76-82.

2. Hatrick CD, Eakle WK, Bird WF. Dental materials: clinical applications for dental assistants and dental hygienists. $2^{\text {nd }}$ ed. St. Louis: Elsevier Inc.; 2011. p. 49-56.

3. Annusavice KJ. Phillips' science of dental material. $11^{\text {th }}$ ed. St. Louis: Saunders Co.; 2011. p. 43, 76, 96-98, 400-439, 655-663, 703704.

4. Margeas RC. Composite restoration esthetics. Course presentation. The Academy of Dental Therapeutics and Stomatology. 2009 [updated 2009; cited 2012 Jun 11]. Available from: www.ineedce.com.

5. Charlton DG. Resin composites. 2012 [updated 2012; cited 2012 Mar 13]. Available from: http://www.homesteadschools.com/dental/ courses/ResinComposites/ResinComposites. pdf charlton resin composite

6. Nielsen MS. Interface structure and strength in model dental resin composites. Ph.D. Thesis. Denmark: DTU Nanotech, Technical University 
of Denmark; 2010.

7. Callister WD. Materials science and engineering: An introduction. USA: New York, John Wiley \& Sons, Inc.; 2007. p. 155-60, 440-1.

8. Gawet B, Gawet K, Øye G. Sol-gel synthesis of non-silica monolithic materials. Materials 2010;3:2815-33.

9. Febrian R. Sintesis dan karakterisasi timah oksida ( $\mathrm{SnO2}$ ) nanowire menggunakan template membran cangkang telur untuk aplikasi anoda baterai ion lithium. Minor Thesis. Bandung: Physics Engineering, Bandung Institute of Technology; 2011.

10. Yang D, Qi L, Ma J. Hierarchically ordered networks comprising crystalline $\mathrm{ZrO} 2$ tubes through sol-gel mineralization of eggshell membranes. J Mater Chem 2003;13:1119-23.

11. Pinho ED, Martins A, Araujo JV, Reis RL, Neves NM. Degradable particulate composite reinforced with nanofibers for biomedical applications. Acta Biomater 2009;5(4):110414.

12. Karaosmanoğlu ÖV, Uzun G, Turan O. Energy dispersive X-Ray (EDX) and wavelength dispersive X-ray spectroscopy (WDX). Presentation Materials. KMÜ 396: HÜ Chemical Engineering Department; 2010. Available from: yunus.hacettepe.edu.tr/ selis/teaching/ WEBkmu396/ppt/Presentations2010/ EDXandWDX.pdf.

13. Loehman RE. Characterization of ceramics. Greenwich: Manning Publications Co.; 1993. p. $4,11,18$.

14. Stadtländer CTKH. Scanning electron microscopy and transmission electron microscopy of mollicutes: challenges and opportunities. In: Mendez-vilas A, Diaz J. Modern research and educational topics in microscopy. Conference Proceeding Formatex 2007; 2007. p. 122-31. Available from: formatex.org/microscopy3/ pdf/pp122-131.pdf.

15. McCabe JW, Angus WG. Applied dental materials. $9^{\text {th }}$ ed. Oxford, UK: Blackwell Munksgaard; 2008. p. 265-6.

16. Foroutan F, Javadpou J, Khavandi A, Atai M, Rezaie HR. Mechanical properties of dental composite materials reinforced with micro and nano-size $\mathrm{Al}_{2} \mathrm{O}_{3}$ filler particles. Iranian J Mat Sci Eng 2011;8(2):25-33. Available from: http:// ijmse.iust.ac.ir/article-1-338-en.html.

17. Evalyna A. Sintesis dan analisis mikrostruktur $\mathrm{Al}_{2} \mathrm{O}_{3}-\mathrm{SiO}_{2}-\mathrm{ZrO}_{2}$ berukuran nano sebagai bahan pengisi restorasi mahkota jaket resin polymethylmethacrylate heatcured serta $u j i$ sifat mekanisnya. Thesis. Bandung: Dental Material and Technology Science Faculty of Dentistry, Universitas Padjadjaran; 2010.

18. Putri TPS. Pengaruh kitosan dan jenis stabilizer (magnesia dan calcia) dalam filler zirkonia terhadap nilai kekerasan nanokomposit untuk bahan restorasi gigi. Minor Thesis. Bandung: Dental Material and Technology Science Faculty of Dentistry, Universitas Padjadjaran; 2011. 